\title{
Antalya Çukuryayla Merasının Vejetasyon Özellikleri ve Otlatma Kapasitesinin Belirlenmesi
}

\author{
Ahmet Alper Babalık ${ }^{1 *}$, Farhat Matrasulov ${ }^{2}$ \\ ${ }^{1}$ Isparta Uygulamalı Bilimler Üniversitesi, Orman Fakültesi, Orman Mühendisliği Bölümü, Isparta, Türkiye (ORCID: 0000-0001-9365-1088) \\ ${ }^{2}$ Isparta Uygulamalı Bilimler Üniversitesi, Lisansüstü Eğitim Enstitüsü, Isparta, Türkiye (ORCID: 0000-0001-7762-4688)
}

(İlk Geliş Tarihi 16 Ağustos 2020 ve Kabul Tarihi 13 Ekim 2020)

(DOI: 10.31590/ejosat.781335)

ATIF/REFERENCE: Babalık, A.A. \& Matrasulov, F. (2020). Antalya Çukuryayla Merasının Vejetasyon Özellikleri ve Otlatma Kapasitesinin Belirlenmesi. Avrupa Bilim ve Teknoloji Dergisi, (20), 327-333.

$\ddot{O ̈ z}$

Bu çalışma, Antalya ili Kemer ilçesi sınırları içerisinde bulunan Tahtalı Dağı'nın eteklerinde yer alan, ortalama 1630 metre yükseltiye sahip Çukuryayla merasında, 2019 yılı vejetasyon periyodunda yapılmıştır. Çalışmada doğal bir meranın vejetasyon özellikleri ve otlatma kapasitesinin belirlenmesi amaçlanmıştır. Araştırma alanında toğrağın bitki ile kaplanma durumu, topraküstü biyokütle, toprakaltı biyokütle, botanik kompozisyon, mera durumu, otlatma kapasitesi ve bazı toprak özellikleri incelenmiştir. Çalışma alanında vejetasyon yapısı incelenmiş olup, 23 familyaya ait 82 adet bitki taksonu tespit edilmiştir. Çalışma sahasındaki bitkilerin toprağı kaplama oranı \%50.4 olarak belirlenmiştir. Botanik kompozisyonun \%54.92'si buğdaygillerden, \%30.22'si diğer familyalardan ve \%14.86'sı baklagillerden oluşmaktadır. Merada topraküstü biyokütle miktarı $309.0 \mathrm{~kg} / \mathrm{da}$, toprakaltı biyokütle miktarı ise $399.0 \mathrm{~kg} / \mathrm{da}$ olarak saptanmıştır. Mera durumu orta olarak bulunmuştur. Otlatma kapasitesi 179 BBHB olarak hesaplanmıştır. Araştırma sahas topraklarının tekstür sınıfı killi toprak olarak bulunmuştur. Toprakların ortalama hacim ağırlığı $1.217 \mathrm{gr} / \mathrm{cm}^{3}$, tuzluluk miktarı 0.305 $\mathrm{dS} / \mathrm{m}$, pH miktarı 7.82, kireç miktarı \%1.23, organik madde miktarı \%2.56 olarak tespit edilmiştir. Ayrıca Ca, $\mathrm{K}, \mathrm{Mg}$ ve P miktarları sırasıyla 10041.8 ppm, 281.6 ppm, $1211.2 \mathrm{ppm}$ ve $6.3 \mathrm{ppm}$ olarak bulunmuştur. Araştırma sonucunda, meranın yoğun otlatma baskısı altında olduğu ve sahadaki vejetasyonun da tahrip edildiği belirlenmiştir. Bu durum mera alanının uygun ıslah yöntemleri ile 1slah edilerek iyileştirilmesi ve otlatma baskısının da azaltılarak kaliteli bitki örtüsünün arttırılması gerektiğini ortaya koymaktadır.

Anahtar Kelimeler: Çukuryayla merası, Biyokütle, Botanik kompozisyon, Otlatma kapasitesi, Antalya.

\section{Determination of Vegetation Characteristics and Grazing Capacity of Çukuryayla Pasture in Antalya}

\begin{abstract}
This research was carried out during the vegetation period of 2019 in the Çukuryayla Pasture, with an average elevation of 1630 meters, located in the Tahtal Mountain, located within the borders of Kemer district of Antalya province. In this study, it was aimed to determine the vegetation characteristics and grazing capacity of a natural pasture. In the research area, plant-covered area, aboveground biomass, belowground biomass, botanical composition, pasture condition, grazing capacity and some soil properties were investigated. In the study area, the vegetation structure was examined and 82 taxa belonging to 23 families were determined. The plant-covered area of the study area was determined as $50.4 \%$. The botanical composition of the pasture area consists of $54.92 \%$ Poaceae, $14.86 \%$ Fabaceae, and $30.22 \%$ other families. The amount of aboveground biomass in the pasture was determined as 309.0 $\mathrm{kg} / \mathrm{da}$ and the amount of belowground biomass was $399.0 \mathrm{~kg} / \mathrm{da}$. Pasture condition was found to be moderate. Grazing capacity was calculated as 179 animal units. The texture class of the research area soils was determined as clay soil. The average bulk density of the soils was $1.217 \mathrm{~g} / \mathrm{cm}^{3}$, salinity was $0.305 \mathrm{dS} / \mathrm{m}, \mathrm{pH}$ was 7.82 , lime was $1.23 \%$, and organic matter was $2.56 \%$. In addition, $\mathrm{Ca}, \mathrm{K}, \mathrm{Mg}$ and $\mathrm{P}$ amounts were found as $10041.8 \mathrm{ppm}, 281.6 \mathrm{ppm}, 1211.2 \mathrm{ppm}$ and $6.3 \mathrm{ppm}$, respectively. As a result of the research, it was determined that the pasture was under intense grazing pressure and the vegetation on the field was also destroyed. This situation reveals that the pasture area should be improved by with appropriate rehabilitation methods and the quality of vegetation should be increased by reducing the grazing intensity.
\end{abstract}

Keywords: Çukuryayla pasture, Biomass, Botanical composition, Grazing capacity, Antalya.

\footnotetext{
* Sorumlu Yazar: Isparta Uygulamalı Bilimler Üniversitesi, Orman Fakültesi, Orman Mühendisliği Bölümü, Isparta, Türkiye, ORCID: 0000-00019365-1088, alperbabalik@isparta.edu.tr
} 


\section{Giriş}

Mera alanları, yeryüzünde hayvan otlatmak suretiyle değerlendirilen ve genellikle otsu bitkilerin hakim olduğu doğal ya da yapay otlatma alanlarıdır (Tiedeman ve Motsamail, 1981). Meralar, esas olarak hayvansal üretim sağlamakla birlikte; toprağı koruyarak, su ve rüzgar erozyonunu da önlemekte, böylece sürdürülebilir bir çevrenin korunmasında en önemli unsuru oluşturmaktadır. Ülkemizdeki mera alanları 1940'larda 44 milyon ha civarında iken, geçen süreç içerisinde, sürekli azalarak 1980'li yıllarda 21.7 milyon ha'a kadar düşmüştür (Altın vd., 2011). 2000'li yıllara gelindiğinde yaklaşık olarak 3/4 oranında azalmıştır. Günümüzde ise mera alanı 14.6 milyon ha'dır (TÜİK, 2018). Bu zaman aralığında, bir BBHB'ne düşen mera alanı 4.45 ha olup, günümüzde ise 0.85 ha'a gerilemiştir (Gökhan, 2003). Son yıllarda yapılan çalışmalara göre, ülkemizde üretilen toplam yem miktarı yıllık 53.7 milyon ton olup, bu üretimin 11.7 milyon tonu çayır ve meralardan, 42.0 milyon tonu yem bitkileri ekili alanlardan temin edilmektedir. Ülkemizde mevcut hayvan varlığını besleyecek kaliteli kaba yem ihtiyacımız ise yıllık 83.9 milyon tondur. Buna göre kaliteli kaba yem açı̆̆ımız yaklaşık 30 milyon tondur (Özkan ve Demirbağ, 2016).

Mera alanları, sürdürülebilir hayvansal üretim sağlayan en önemli ekosistemlerden biri olup, aynı zamanda özellikle otsu bitkiler için biyolojik çeşitlilik ve gen kaynağ oluşturmaktadırlar (Dumlu, 2010). Türkiye bitki tür çeşitliliği açısından çoğu Avrupa ülkesinden daha zengin bir floraya sahiptir. Avrupa kıtasında yaklaşık 12.000 takson ve 2.750 endemik bitki taksonu bulunurken, çok daha küçük bir alana sahip olan Türkiye'de 11.000'in üzerinde bitki taksonu yer almakta olup, bu taksonlardan 3.649 tanesi de endemiktir (Aksakal ve Kaya, 2005). Antalya florası da oldukça zengin bir yapıya sahip olup endemizm bakımından dikkat çekici alanlar olduğu bilinmektedir (Fener, 2018). Antalya ilinde yayılış gösteren endemik bitki taksonlarının 250'ye yakını Antalya endemiği olarak bilinmektedir (Deniz ve Aykurt, 2014).

Ülkemiz meralarının kapasitelerinin üzerinde aşırı otlatılması nedeniyle bitki örtülerinin büyük bir kısmı klimaks vejetasyondan uzaklaşmış durumdadır (Sönmeyen, 2019). Kontrolsüz, erken ve aşırı otlatma mera alanlarının tahribine sebep olurken, meraların durumlarının belirlenmesi ve uygulanabilecek ıslah methotlarının saptanması konusunda da yapılmış kapsamlı çalışmalar oldukça azdır (Gökkuş vd., 1995;
Tosun, 1996). Klimaks bitki örtülerini büyük ölçüde kaybeden meraların, verimli ve kaliteli yem üretim kapasitelerine yeniden gelebilmeleri için bu alanların acil olarak 1slah edilmeleri sağlanmalıdır (Uzun vd., 2009). Herhangi bir merada uygulanacak ıslah ve amenajman çalışmalarına başlamadan önce o yerin toprak ve vejetasyon yapısı ile vejetasyonun çeşitli kalitatif ve kantitatif özelliklerinin bilinmesi gerekmektedir. Bu özelliklerin belirlenmesi ise, ancak vejetasyon üzerinde uygulanan çeşitli etüt ve ölçme yöntemleri ile laboratuvar yöntemleri sonucunda ortaya konulur. $\mathrm{Bu}$ yöntemler sayesinde bir merada uygulanan ıslah ve amenajman yöntemlerinin bitki örtüsü üzerindeki etkileri de kolayca incelenmiş olur (Okatan, 1987).

Antalya yöresi meralarının kullanımında da ülkemizin birçok yöresindeki meralarda olduğu gibi, herhangi bir amenajman ilkesine uyulmamaktadır. $\mathrm{Bu}$ sebepten dolayı bozulan mera alanlarının tekrar verimli haline dönüştürülmesi, mevcut alanların ıslahında, bitki örtüsü ile onu etkileyen toprak, topografya ve diğer çevre koşullarının araştırılması ve bunlar arasındaki ilişkilerin de bilinmesi gerekmektedir. Araştırma alanı Antalya ili Kemer ilçesi Çukuryayla merası ile ilgili vejetasyon açısından daha önceden yapılmış bir çalışmaya rastlanılmamıştır. Yaklaşık 1500-1800 m rakıma sahip olan Toros Dağlarındaki Çukuryayla merasında yıllardır süre gelen yaylacılık sistemi uygulanmaktadır. Meranın vejetasyon durumunun, yem bitkileri potansiyelinin, bitki tür çeşitliliğinin ve otlatma kapasitesinin ortaya konulması açısından, araştırma kapsamında bitkilerin yayılışını etkileyen ve flora özelliklerinin daha iyi anlaşılmasını sağlayan topoğrafya, iklim, toprak ve vejetasyon özellikleri araştırılmıştır. Araştırmanın temeli floristik kompozisyonun, meranın topraküstü ve toprakaltı biyokütle miktarlarının, erozyon açısından son derece önem arz eden bitki ile kaplı alan durumunun ve otlatma kapasitesinin belirlenmesine dayanmaktadir.

\section{Materyal ve Metot}

\subsection{Materyal}

Antalya ili Kemer ilçesi Yayla Kuzdere sınırları içerisinde yer alan, 1630 metre ortalama rakıma ve batı genel bakısına sahip olan, 313 hektar büyüklüğündeki Tahtalı Dağı Çukuryayla Merası araştırma materyali olarak belirlenmiştir (Şekil 1). Araştırma sahası il merkezine $47 \mathrm{~km}$ mesafede bulunmaktadır. Mera alanının koordinatları 36²32'54.2"N 30²4'36.9"E olarak tespit edilmiştir.

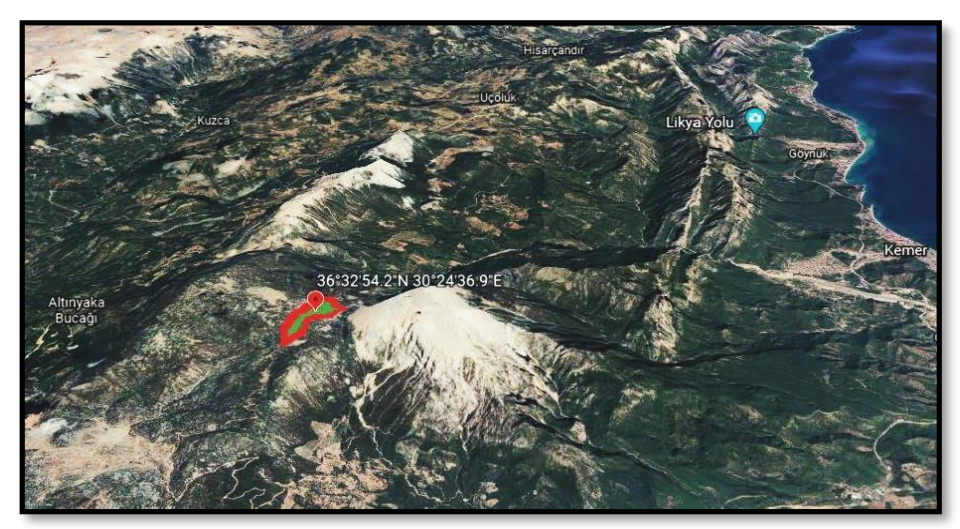

Şekil 1. Çukuryayla merasının konumu 
Çalışma, 2019 yılı vejetasyon dönemi içerisinde yürütülmüştür. Türlerin ülkemizde yayılışlarının daha kolay izlenebilmesi için Davis (1964-1985)'in önerdiği Grid sistemine göre, araştırma alanı C3 karesi içerisinde yer almaktadır. Antalya havzası oldukça farklı iklim, toprak ve topoğrafya şartlarına sahip olduğundan bitki örtüsünde de çeşitlilik görülmektedir.

Araştırma sahasının iklim durumunu belirlemek amacıyla bölgeye en yakın konuma sahip olan, Kemer ilçesi Ovacık köyü meteoroloji istasyonu verilerinden yararlanılmıştır. Veriler Antalya Meteoroloji 4. Bölge Müdürlüğü'nden temin edilmiştir (DMİ, 2020). Araştırmanın yürütüldüğü 2019 yılı ve uzun yıllar ortalamasına (UYO) ait bitki gelişimine en çok etki yapan iklim faktörlerinden aylık yağış toplamı, ortalama sıcaklık ve ortalama nispi nem değerleri Tablo1'de verilmiştir (DMİ, 2020).

Tablo 1. Çalışma alanının 2019 yılı ve uzun yıllar ortalamasına ait bazı iklim verileri

\begin{tabular}{|c|c|c|c|c|c|c|c|c|c|c|c|c|c|}
\hline $\begin{array}{l}\text { Yll/ } \\
\text { Ay }\end{array}$ & Ocak & Şubat & Mart & Nisan & Mayıs & Haziran & Temmuz & Ağustos & Eylül & Ekim & Kasım & Aralık & $\begin{array}{l}\text { Toplam/ } \\
\text { Ortalama }\end{array}$ \\
\hline \multicolumn{14}{|c|}{ Aylık Ortalama Sıcaklık $\left({ }^{\circ} \mathrm{C}\right)$} \\
\hline 2019 & 2.8 & 4.8 & 7.3 & 9.8 & 16.9 & 20.8 & 23.3 & 24.5 & 20.5 & 17.0 & 11.8 & 6.4 & 13.8 \\
\hline UYO & 4.1 & 5.65 & 8.1 & 12.4 & 17.15 & 19.95 & 23.45 & 23.2 & 20.8 & 15.6 & 10.5 & 6.1 & 13.9 \\
\hline \multicolumn{14}{|c|}{ Aylık Toplam Yağıș (mm) } \\
\hline 2019 & 529.2 & 230.9 & 70.3 & 61.7 & 10.8 & 59.8 & 2.8 & 4.6 & 6.9 & 32.2 & 308.3 & 232.0 & 1546.7 \\
\hline UYO & 311.6 & 185.5 & 65.7 & 32.2 & 19.5 & 65.6 & 39.8 & 7.8 & 6.9 & 30.9 & 136.6 & 414.1 & 1316.5 \\
\hline \multicolumn{14}{|c|}{ Aylık Ortalama Nispi Nem (\%) } \\
\hline 2019 & 84.5 & 77.2 & 71.6 & 69.7 & 57.4 & 60.0 & 49.6 & 46.8 & 56.6 & 61.6 & 71.0 & 75.5 & 65.4 \\
\hline UYO & 77.9 & 79.4 & 73.5 & 58.6 & 58.6 & 64.8 & 52.4 & 54.6 & 53.0 & 55.5 & 68.9 & 78.2 & 64.6 \\
\hline
\end{tabular}

Araştırma alanının UYO toplam yağış miktarı $1316.5 \mathrm{~mm}$ iken, çalışmanın yürütüldüğü yıldaki toplam yağış miktarı $1546.7 \mathrm{~mm}$ ile UYO toplamından daha fazla bulunmuştur. 2019 yılında en az yağış $2.8 \mathrm{~mm}$ ile Temmuz ayında belirlenirken, en fazla yağış $529.2 \mathrm{~mm}$ ile Ocak ayında tespit edilmiştir. Araştırma alanı uzun yıllar ortalaması sicaklık değeri $13.9{ }^{\circ} \mathrm{C}$ olup, 2019 yılında ortalama sicaklık $13.8{ }^{\circ} \mathrm{C}$ olarak bulunmuştur. En sıcak aylar Temmuz ve Ağustos ayları olup, Ocak ve Şubat ayları ise en soğuk aylar olarak belirlenmiştir. Araştırma alanı UYO nispi nem miktarı \%64.6 olup, 2019 yılında toplam nispi nem miktarı \%65.4 olarak daha yüksek bulunmuştur (Tablo 1).

\subsection{Metot}

Çalışmada mera vejetasyonunun kantitatif özelliklerini belirlemek amacıyla transekt ve kuadrat yöntemlerinden (Genç Lermi vd., 2016; Gökbulak, 2013) faydalanılmıştır. Mera alanının bitki ile kaplı alan ve botanik kompozisyon oranını belirlemek için, ülkemizde vejetasyon ölçüm çalışmaları yürüten Altın ve Tuna (1991), Gökkuş ve Koç (1996), Bakoğlu ve Koç (2002), Altın vd., (2007), Gür (2008), Babalık (2008) gibi araştırmacılar tarafından da tercih edilen transekt yönteminden yararlanılmıştır. Mera vejetasyonunun özelliklerini saptamak amacıyla mera alanında 5 adet ana transekt hattı belirlenmiş, her hatta 10 transekt ünitesi olacak şekilde vejetasyon ölçümleri yapılmıştır. Topraküstü biyokütle ve toprakaltı biyokütle miktarlarının tespitinde ise Babalık (2008) ve Gökbulak (2013) gibi araştırmacılar tarafından da tercih edilen kuadrat yöntemi kullanılmıştır. Bunun için 1x1 $\mathrm{m}^{2}$ 'lik kuadratlardan yararlanılmıştır. Her transekt hattında rastgele 5'er adet, toplamda 25 adet $1 \mathrm{~m}^{2}$ 'lik alanlarda biyokütle ölçümleri yürütülmüştür. Ayrıca araştırmada meranın otlatma kapasitesi ve mera durumu da belirlenmiştir. Vejetasyon ölçümleri, 2019 yılı vejetasyon periyodu içerisinde Haziran ve Ekim aylarında yaz ve güz dönemi ölçümleri olarak gerçekleştirilmiştir.
Çalışma alanının genel toprak yapısını incelemek amacıyla, meranın değişik kesimlerinden rastgele örnekleme ile araziyi kapsayacak şekilde $0-20 \mathrm{~cm}$ derinlik kademesinden 25 adet toprak örneği alınmış ve laboratuvar ortamında bu örneklerin; tekstür sınıfı, organik madde miktarı, $\mathrm{pH}$ değerleri, tuzluluk oranları, hacim ağırlıkları, kireç miktarı, dispersiyon oranı ve bitkilerin bazı besin elementleri tayin edilmiştir.

Mera alanındaki ölçümler ve laboratuvarda yapılan analizlerle ortaya çıkan verilerin değerlendirilmesinde istatistik yöntemlerden yararlanılmıştır. Bu analizler yapılırken, verilerin normal dağılımlı olup olmadığı "Kolmogorov-Smirnov testi" ile belirlenmiştir. Varyansların homojenliğinin belirlenmesinde ise "Levene testi" nden yararlanılmıştır. Vejetasyon özelliklerinin Haziran ve Ekim aylarındaki ölçümlerde gösterdikleri farklılıkların istatistiksel anlamda önemli olup olmadığı ise "Bağımsız örnekleme t-testi" ile değerlendirilmiştir. Verileri değerlendirmede SPSS 20.0 paket programı kullanılmıştır.

\section{Araştırma Sonuçları ve Tartışma}

Mera alanının genel toprak yapısını ortaya koymak için Çukuryayla merasından alınan toprak örneklerinin analizleri sonucu, meradaki toprağın killi toprak tekstür sınıfına girdiği belirlenmiştir. Topraktaki kireç miktarının \%1.23 ile kireçsiz, organik madde miktarının ise \%2.56 ile orta olduğu analizler sonucu ortaya çıkmıştır. Çalışılan meradaki toprağın pH'sı 7.82 ile hafif alkalin, elektriksel iletkenliği $0.305 \mathrm{dS} / \mathrm{m}$ ile tuzsuz toprak olarak bulunmuştur. Mera toprağının ortalama hacim ağırlığı değeri $1.217 \mathrm{~g} / \mathrm{cm}^{3}$ olarak belirlenmiştir. Mera toprağının makro besin elementlerinden magnezyum değerlerinin çok yüksek, potasyum ve kalsiyum değerinin yüksek, fosfor değerinin ise düşük düzeyde olduğu tespit edilmiştir. Bununla birlikte dispersiyon oranı $\% 62.14$ olarak bulunmuş ve mera 
toprağının erozyona duyarlı olduğu ortaya konulmuştur (Tablo 2).

Tablo 2. Çukuryayla merasının toprak analiz sonuçları

\begin{tabular}{|l|c|c|}
\hline Analiz Adı & Sonuçlar & Değerlendirme \\
\hline Tekstür (\%) & $27-23-50$ & Killi \\
EC (dS/m) & 0.305 & Tuzsuz \\
pH & 7.82 & Hafif Alkalin \\
Kireç (\%) & 1.23 & Kireçsiz \\
Organik Madde (\%) & 2.56 & Orta \\
Hacim Ağırlığı $\left(\mathrm{gr} / \mathrm{cm}^{3}\right)$ & 1.217 & Normal \\
P (ppm) & 6.33 & Düşük \\
Ca (ppm) & 10041.82 & Yüksek \\
K (ppm) & 281.60 & Yüksek \\
Mg (ppm) & 1211.23 & Çok Yüksek \\
Dispersiyon Oranı $(\%)$ & 62.14 & Erozyona Duyarlı \\
\hline
\end{tabular}

Bitkiyle kaplı alan (BKA) değerleri Haziran ayında \%54.44, Ekim ayında ise \%46.40 olarak tespit edilmiştir. Ortalama bitki ile kaplı alan değeri ise \%50.42 olarak belirlenmiştir. Bu bağlamda mera alanında BKA değeri \%30'un üzerinde olduğu için $(\% 50.42)$ bitki örtüsünün toprağ 1 yeterince örttüğünü ve erozyona karşı direncinin yüksek seviyede olduğunu söylemek mümkündür. BKA bakımından mera alanında yapılan yaz ve güz dönemi ölçümleri arasında ( $\mathrm{t}=7.032) \% 99.9$ güven düzeyinde önemli fark tespit edilmiştir. Ülkemizin farklı yörelerinde bitki ile kaplı alan üzerine yapılmış olan çalışmalara göre bitki ile kaplı alan yüzdeleri; Ankara ili Ayaş ilçesinde \%14.5 (Kendir, 1999), Bayburt ili Çiğdemlik köyünde \%31.5 (Erkovan, 2000), Mersin ili Tarsus ilçesi Oluk Koyak köyünde \%47.7 (Türker, 2006), Isparta ili Davraz dağı Kozağacı yaylasında \%23.1 (Babalık, 2007) ve Bingöl ili Yedisu ilçesinde \%85.8 (Ağın ve Kökten, 2013) olarak bulunmuştur. Araştırma bulguları ile yapılan çalışmalar kıyaslandığında BKA değerleri bazı çalışmalardan daha yüksek çıkarken, bazılarından ise düşük bulunmuştur. Bitki ile kaplı alan değerleri arasında farklılıklar çıkmasında, merada yapılan otlatmanın yoğunluğu ile birlikte, topoğrafik faktörler ve iklim faktörlerinin de etkili olduğu düşünülmektedir.

Çalışma alanındaki bitkiler üç grup halinde (buğdaygiller familyası, baklagiller familyası ve diğer familyalar) incelenerek BKA'ya göre botanik kompozisyondaki oranları belirlenmiştir (Tablo 3).

Tablo 3. Mera alanının bitki ile kaplı alana göre botanik kompozisyon de ğerleri

\begin{tabular}{|l|c|c|c|}
\hline \multirow{2}{*}{ Familyalar } & \multicolumn{3}{|c|}{ Botanik Kompozisyon (\%) } \\
\cline { 2 - 4 } & Yaz & Güz & Ortalama \\
\hline Buğdaygiller & 57.68 & 52.16 & 54.92 \\
\hline Baklagiller & 15.06 & 14.65 & 14.86 \\
\hline Diğer Familyalar & 27.26 & 33.19 & 30.22 \\
\hline Toplam & 100.00 & 100.00 & 100.00 \\
\hline
\end{tabular}

Botanik kompozisyon familyalara göre incelediğinde; kompozisyonun \%54.92'sini buğdaygiller familyası oluşturmaktadır. Buğdaygiller familyasını \%30.22 ile diğer familyalar takip etmektedir. Araştırma alanında en az orana sahip familya \%14.86 ile baklagiller familyasıdır. $\mathrm{Bu}$ sonuçlar buğdaygillerin alanda baskın olduğunu göstermektedir. Ayrıca yaz ve güz ölçümleri incelendiğinde; buğdaygillerin \%52.16 ve baklagillerin \%14.65 ile yaz ölçümüne göre güz ölçümü sonucunda bir miktar azaldığı, diğer familyaların ise \%33.19 ile güz ölçümlerinde arttığı görülmektedir. Bu sonuçlar iklimsel değişikliklerin ve mevsimlere göre otlatma zamanı gibi farklılıkların familyalar düzeyinde etkili olduğunu göstermektedir. Çeşitli yörelerde farklı araştırmacılar tarafından yapılan çalışmalardaki botanik kompozisyon değerleri (buğdaygiller, baklagiller, diğer familyalar sırasıyla) aşağıda verilmiştir. Edirne'de Keşan ilçesi Kalatepe mevkiinde \%59.6\%16.4-\%24.0 (Tekeli ve Mengül, 1991), Burdur ili Ağlasun ilçesi orman içi merasında \%53.9-\%21.5-\%24.6 (Özen ve Türk, 2014), Ankara ilinde bir merada \%47.0-\%4.6-\%48.6 (Çelik, 2015), Eskişehir ili Seyitgazi ilçesinde \%44.3-\%22.5-\%33.2 (Ercan, 2018), Antalya ili Kaş ilçesinde \%47.4-\%21.0-\%31.6 (Sönmeyen, 2019) olarak botanik kompozisyon değerleri belirlenmiştir. Çeşitli araştırmacılar tarafından yapılan botanik kompozisyon çalışmalarıyla bulgularımız arasındaki farklılıkların, farklı iklim özellikleri ve topoğrafik unsurlar başta olmak üzere otlatma yoğunluğundaki farklılıklardan kaynaklandı̆̆ı söylenebilir.

Mera alanındaki ölçümler sonucunda topraküstü biyokütle (TÜB) miktarı ortalama $309.0 \mathrm{~kg} / \mathrm{da}$ olarak tespit edilmiştir. Haziran ayında yapılan ölçümlerde topraküstü biyokütle 336.8 $\mathrm{kg} / \mathrm{da}$ iken, Ekim ayında azalarak $281.2 \mathrm{~kg} / \mathrm{da}$ 'a düşmüştür. TÜB bakımından merada yapılan yaz ve güz dönemi ölçümleri arasında ( $\mathrm{t}=11.293) \% 99.9$ güven düzeyinde önemli fark tespit edilmiştir. Ülkemizin değişik bölgelerinde çeşitli araştırmacılar tarafından yapılan çalışmalarda topraküstü biyokütle değerleri; Osmaniye ilinde $283.9 \mathrm{~kg} / \mathrm{da}$ (Özer, 1988), Tokat ilinde 359.0 $\mathrm{kg} / \mathrm{da}$ (Yılmaz ve Büyükburç, 1996), Giresun ilinde $241.0 \mathrm{~kg} / \mathrm{da}$ (Akdeniz vd., 2003), Kars ilinde 337.5 kg/da (Demirkıran, 2014) ve Edirne ilinde $391.0 \mathrm{~kg} / \mathrm{da}$ (Kurt, 2016) olarak belirlenmiştir. Elde ettiğimiz bulgular, Özer (1988) ile Akdeniz vd. (2003) tarafindan elde edilen bulgulardan daha yüksek çıkarken, Yılmaz ve Büyükburç (1996), Demirkıran (2014) ile Kurt (2016)'un tespit etmiş olduğu TÜB değerlerinden daha düşük bulunmuştur. $\mathrm{Bu}$ farklılıkların oluşmasında, iklim özellikleri ve farklı topoğrafik unsurlar başta olmak üzere değişik otlatma yoğunluklarının da etkili olduğu söylenebilir.

Çukuryayla merasında yapılan ölçümler sonucunda ortalama toprakaltı biyokütle (TAB) miktarı $399.0 \mathrm{~kg} / \mathrm{da}$ olarak tespit edilmiştir. Haziran ayında yapılan ölçümlere göre 410.6 $\mathrm{kg} / \mathrm{da}$ olan toprakaltı biyokütle miktarı, Ekim ayı ölçümlerinde biraz azalarak $387.4 \mathrm{~kg} / \mathrm{da}$ olarak belirlenmiştir. TAB bakımından merada yapılan yaz ve güz dönemi ölçümleri arasında da ( $\mathrm{t}=5.481) \% 99.9$ güven düzeyinde önemli fark tespit edilmiştir. Değişik bölgelerde çeşitli araştırmacıların yapmış 
oldukları çalışmalarda TAB değerleri; Isparta ili Aksu ilçesinde $398.0 \mathrm{~kg} / \mathrm{da}$ (Dursun, 2017), Eskişehir ili Seyitgazi ilçesinde $560.7 \mathrm{~kg} / \mathrm{da}$ (Ercan, 2018) ve Antalya ili Kaş ilçesinde 307.2 $\mathrm{kg} / \mathrm{da}$ (Sönmeyen, 2019) olarak bulunmuştur. TAB değerlerinin, Dursun (2017)'un çalışma sonuçlarına yakın olduğu, Ercan (2018)'ın çalışma sonuçlarından daha düşük bulunduğu, Sönmeyen (2019)'in yaptı̆̆ı çalışma sonuçlarından ise daha yüksek olduğu tespit edilmiştir. Bu farklılıkların oluşmasında, iklim özellikleri ve topoğrafik faktörler başta olmak üzere merada neredeyse yıl boyunca devam eden otlatmanın da etkili olduğu düşünülmektedir.

Yaz ve güz dönemlerinde merada yapılan vejetasyon ölçümlerinden elde edilen bitki ile kaplı alan değerlerinin mera durumu skalası ile karşılaştırılması sonucu elde edilen mera durumu değerleri Tablo 4'de verilmiştir.

Tablo 4. Mera durumu değerleri

\begin{tabular}{|l|c|c|}
\hline Mevsimler & BKA $(\%)$ & Mera Durumu \\
\hline Yaz Ölçümü & $\% 54.44$ & İyi \\
\hline Güz Ölçümü & $\% 46.40$ & Orta \\
\hline Ortalama & $\% 50.42$ & Orta \\
\hline
\end{tabular}

Çalışma alanının bitki ile kaplı alan değerlerine göre belirlenen mera durumu yaz dönemi ölçümlerinde "iyi” olarak belirlenirken, güz dönemi ölçümlerinde "orta" olarak tespit edilmiştir (Tablo 4). Dolayısıyla mera alanının ortalama mera durumu da "orta" olarak bulunmuştur. Ülkemizin değişik bölgelerinde yapılmış olan çalışmalar incelendiğinde; Uluocak (1978)'ın Kurklareli ilinde, Öner (2006)'in Erzurum ilinde, Dursun (2017)'un Isparta ilinde ve Sönmeyen (2019)'in Antalya ilinde yapmış oldukları araştırmalarda mera durumunu orta olarak belirledikleri görülmektedir.

Meranın otlatma kapasitesi 180 günlük otlatma periyodu için 179 BBHB olarak hesaplanmıştır. Bir BBHB için gerekli mera alanı ise 1.75 ha olarak bulunmuştur. Farklı yörelerde yapılan çalışmalarda; Adana ili Tufanbeyli ilçesi Hanyeri köyünde otlatma kapasitesi 268 BBHB ve hayvan başına düşen mera alanı 2.21 ha (Çınar, 2001), Kahramanmaraş ili Ahır dağında otlatma kapasitesi 882 BBHB ve hayvan başına düşen mera alanı 4.72 ha (Şen, 2012) ve Elazığ ili Karakoçan ilçesi Bahçecik köyünde otlatma kapasitesi 327 BBHB ve hayvan başına düşen mera alanı 1.87 ha (Taşdemir, 2015) olarak belirlenmiştir. Bulgular arasındaki farklılıkların yörelerin kendine özgü ekolojik özelliklerinden kaynaklandığı düşünülmektedir.

Araştırma sahasında 23 familyaya ait 71 cins olmak üzere toplam 82 bitki taksonu tespit edilmiştir. Bu 82 taksonun 9'unu buğdaygiller, 5'ini baklagiller, 68'ini ise diğer familyalara ait bitkiler oluşturmaktadır (Şekil 2).

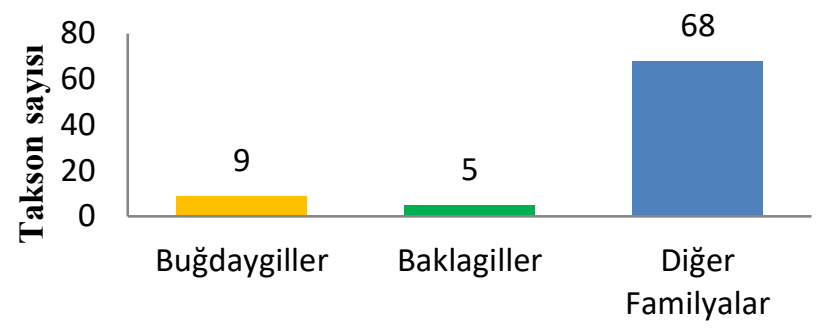

Familyalar

Şekil 2. Bitki taksonlarının familyalara dă̆ılımı

\section{Sonuç}

Araştırma alanının topoğrafik özellikleri nedeniyle yöre halkı keçi beslemektedir ve hayvancılık, yöre halkının en önemli geçim kaynaklarından biri olup bu hayvanlar kışın makilik alanlarda ve orman içinde, yazın ise yaylalarda otlamaktadır. $\mathrm{Bu}$ hayvanlar gelişmekte olan vejetasyon üzerinde yoğun baskı kurmakta ve bitkilerin gelişimini engellemektedir. Böylelikle araştırma alanında hayvanların yemediği kamefit bitkiler giderek dominant duruma gelmektedir. Araştırma alanının uluslararası bir üne sahip olan Antalya ilinde yer alması ve yapılaşmanın çok yoğun olduğu bir kesimde bulunması nedeniyle son yıllarda yüksek dağlık kesimlerde, yaylalarda gerek turizm gerekse tatil amaçlı yapılaşmalar başlamıştır. Yöre halkı doğal bitkilerden ekonomik amaçlı olarak sağlık vb. gibi farklı amaçlarla faydalanmaktadır ve doğal bitkileri bilinçsizce tüketmektedir. Yapılan çalışma sonucunda alandaki mevcut tahribatın nadir ve endemik bitkiler üzerinde baskı oluşturduğu ortaya çıkmaktadır. Araştırma alanının floristik yapısını olumsuz yönde etkileyen otlatma, tarla açma, doğal bitkilerden faydalanma, yapılaşma, yaylacılık faaliyetleri gibi sorunlar belirlenmiştir. Bu bağlamda, yapılaşmanın uygun alanlarda ve çevreye zarar vermeden bir gelişme göstermesi son derece büyük önem arzetmektedir. Bitki kalitesi sorununun çözümü için ise bu alanların acilen 1slah edilmesi gerekmektedir.

Antalya yaylaları aynı zamanda doğal güzellikleri ve çekicilik oluşturan özellikleri nedeniyle eko-turizme yönelik kullanım konusunda hedef haline gelmişlerdir. Ancak, meralarda kontrolsüz bir şekilde yapılan "Çukuryayla Yörük Şenlikleri, Motosiklet Yarışları, Jeep Safari Gezileri, Kamp Alanları” gibi etkinlikler sonucunda toprağın sıkışarak su geçirme özelliğinin azalması ve erozyonun başlaması gibi olumsuz sonuçlara yol açmaktadır. Bunun bir sonucu olarak bitki örtüsü her geçen gün biraz daha fazla tahrip edilmektedir.

Sonuç olarak; mera alanının erken ve aşırı otlatılması başta olmak üzere diğer faktörlerinde etkisiyle meradaki bitki örtüsü büyük oranda tahrip edilmiş durumdadır. Meranın sürdürülebilir bir şekilde yönetilebilmesi için; otlatma kapasitesine uyulmalı, çobanlara konu ile ilgili eğitim verilmeli, aynı zamanda tohumlama ve gübreleme gibi bazı ıslah yöntemleri kullanılarak orta olan mera durumu iyi seviyeye getirilmelidir. Araştırma neticesinde; araştırma alanının biyokütke miktarı, mera durumu, otlatma kapasitesi belirlenmiş olup, konuyla ilgilenen, konuya ilgi duyan kişilere ve ilgili kuruluşlara önemli katkılar sağlayacaktır. Ayrıca Antalya yöresinde, bu çalışma ve benzeri çalışmaların ileriki yıllarda yapılacak olan flora ve mera çalışmalarına belli bir oranda katkıda bulunması ümit edilmektedir. 


\section{Açıklama}

$\mathrm{Bu}$ çalışma, Isparta Uygulamalı Bilimler Üniversitesi Lisansüstü Eğitim Enstitüsü Orman Mühendisliği Anabilim Dalı'nda tamamlanan yüksek lisans tez çalışmasının bir bölümünden hazırlanmıştır.

\section{Kaynakça}

Ağın, Ö. \& Kökten, K. (2013). Bingöl İli Yedisu İlçesi Karapolat Köyü Merasının Botanik Kompozisyonunun Belirlenmesi. Türk Doğa ve Fen Dergisi. 2(1), 41-45.

Akdeniz, H., Kahraman, A. \& Terzioğlu, Ö. (2003). Giresun ili Kümbet (Uzundere) Yaylası kapalı çayır-mera alanlarının yem potansiyeli ve botanik kompozisyonları. Dicle Üniversitesi Ziraat Fakültesi, Türkiye 5. Tarla Bitkileri Kongresi, (s. 632-636). 13-17 Ekim 2003. Diyarbakır.

Aksakal, Ö. \& Kaya, Y. (2005). Endemik Bitkilerin Dünya ve Türkiye'deki Dağılımı. Erzincan Üniversitesi Eğitim Fakültesi Dergisi. 7 (1), 85-99.

Altın, M. \& Tuna, M. (1991). Değişik Islah Yöntemlerinin Banarlı Koyu Doğal Merasının Verim ve Vejetasyonu Üzerindeki Etkileri. Ege Üniversitesi. Ziraat Fakültesi. Türkiye 2. Cayır Mera ve Yem Bitkileri Kongresi, (s. 95105). 28-31 Mayıs, İzmir.

Altın, M., Tuna, C. \& Gür, M. (2007). Bir Islah Çalışmasının Doğal Mera Ekosisteminin Vejetasyonu Üzerindeki Bazı Etkileri. Türkiye VII. Tarla Bitkileri Kongresi, (s. 42-45). 25 -27 Haziran 2007, Erzurum.

Altın, M., Gökkuş, A. \& Koç, A. (2011). Çayır ve Mera Yönetimi: 1. (Genel İlkeler). Ankara. Tarım ve Köy işleri Bakanlığı, Tarımsal Üretim ve Geliştirme Genel Müdürlüğü Yayınları. s. 376. Ankara.

Babalık, A.A. (2007). Davraz Dağı Kozağacı Yaylası Merasında Bitki ile Kaplı Alan ve Otlatma Kapasitesinin Belirlenmesi Üzerine Bir Araştırma. Süleyman Demirel Üniversitesi Orman Fakültesi Dergisi. 1, 12-19.

Babalı, A. A. (2008). Isparta Yöresi Meralarının Vejetasyon Yapısı ile Toprak Özellikleri ve Topoğrafik Faktörler Arasındaki İlişkiler. Süleyman Demirel Ǘniversitesi Fen Bilimleri Enstitüsü. Doktora Tezi, s. 164. İsparta.

Bakoğlu, A. \& Koç, A. (2002). Otlatılan ve Korunan İki Farklı Mera Kesiminin Bazı Toprak ve Bitki Örtüsü Özelliklerinin Karşılaştırılması: I. Bitki Örtüsü Özelliklerinin Karşılaştırılması. Fırat Üniversitesi, Fen ve Mühendislik Bilimleri Dergisi. 14(1), 37-47.

Çelik, A. (2015). Ankara'da otlanan ve otlanmayan iki meranın botanik kompozisyonu ile ot veriminin karşılaştırılması. Ankara Üniversitesi Fen Bilimleri Enstitüsü. Yüksek Lisans Tezi, s. 135. İzmir.

Çınar, S. (2001). Adana ili Tufanbeyli İlçesi Hanyeri Köyü Merasında Verim ve Botanik Kompozisyonun Saptanması Üzerine Bir Araştırma. Çukurova Üniversitesi Fen Bilimleri Enstitüsü. Yüksek Lisans Tezi, s. 78. Adana.

Davis, P.H. (1964-1985). Flora of Turkey and the East Aegean Islands. 1-9, Edinburgh University Press.

Demirkıran, S. (2014). Kars ilinde farklı rakıma sahip Meralarda verim ve Botanik Kompozisyonun değişimi. Iğdır Üniversitesi Fen Bilimleri Enstitüsü. Yüksek Lisans Tezi, s. 62. Iğdır.

Deniz, İ.G. \& Aykurt, C. (2014). Critically Endangered (CR) plant taxa in Antalya province, Herb Journal of Systematic Botany. 21(2), 59-70.
DMİ, (2020). Kemer İlçesi İklim Verileri. Devlet Meteoroloji İşleri Genel Müdürlüğü, Antalya Meteoroloji 4. Bölge Müdürlüğü, Antalya.

Dumlu, S.E. (2010). Ardahan İli Meralarında Uzaktan Algılama ve Coğrafi Bilgi Sistemi Teknikleri ile Sinıflandırılması. Atatürk Üniversitesi Fen Bilimleri Enstitüsü. Yüksek Lisans Tezi, s. 75. Erzurum.

Dursun, İ. (2017). Isparta İli Çatoluk Ormaniçi Merasının Vejetasyon Yapısının Belirlenmesi. Süleyman Demirel Üniversitesi Fen Bilimleri Enstitüsü. Yüksek Lisans Tezi, s. 62. Isparta.

Ercan, A. (2018). Eskişehir İli Seyitgazi İlçesi Karaören Köyü Merasının Bitki Örtüsü Özellikleri ve Mera Durumunun Belirlenmesi. Süleyman Demirel Üniversitesi Fen Bilimleri Enstitüsü. Yüksek Lisans Tezi, s. 73. Isparta.

Erkovan, H.İ. (2000). Çiğdemlik Köyü (Bayburt) mera vejetasyonları mevcut durumu. Atatürk Üniversitesi Fen Bilimleri Enstitüsü. Yüksek Lisans Tezi, s. 50. Erzurum.

Fener, D. (2018). Kıbrıs Çayı Yaban Hayatı Geliştirme Sahası (Kaş/Antalya) Florası. Akdeniz Üniversitesi Fen Bilimleri Enstitüsü. Yüksek Lisans Tezi, s. 202. Antalya.

Genç Lermi, A., Palta, Ş. \& Öztürk, H. (2016). Bartın ilinde bir mera ıslah çalışmasının değerlendirilmesi: Serdar Köyü örneği. Bartın Orman Fakültesi Dergisi. 18(2), 65-70.

Gökbulak, F. (2013). Meralarda Vejetasyon Analizi. İstanbul Üniversitesi Orman Fakültesi Yayınları No: 5151, Orman Fakültesi Yayın No: 503, s. 157.

Gökhan, E.E. (2003). Elâzığ İli Çayır Mera Kaynakları. Doğu Anadolu Bölgesi Araştırmaları Dergisi. 1(3), 42-45.

Gökkuş, A., Koç, A. \& Çomaklı, B. (1995). Çayır-Mera Uygulama Kilavuzu. Erzurum Atatürk Üniversitesi Ziraat Fakültesi Yayınları No: 142, s. 139.

Gökkuş, A. \& Koç, A. (1996). Sürülen Meralarda Bitki ÖrtüsüToprak İlişkileri. Tarım Çevre İlişkileri Sempozyumu. (s. 336-344). 13-15 Mayıs 1996. Mersin.

Gür, M. (2008). Yörükler Köyü Doğal Mera Vejetasyonunun Botanik Kompozisyonu ve Verim Potansiyeli Üzerinde Bir Araştırma. Namık Kemal Üniversitesi, Fen Bilimleri Enstitüsü. Yüksek Lisans Tezi, s. 57. Tekirdağ.

Kendir, H. (1999). Ayaş Ankara'da Doğal Bir Meranın Bitki Örtüsü, Yem Verimi ve Mera Durumu. Ankara Üniversitesi Ziraat Fakültesi Tarım Bilimleri Dergisi, 5(1), 104-110.

Kurt, G. (2016). Kırklareli ili Lüleburgaz ilçesi Doğal Mera Vejetasyonunun Botanik Kompozisyonu ve Verim Potansiyelleri. Namık Kemal Üniversitesi Fen Bilimleri Enstitüsü. Yüksek Lisans Tezi, s. 89. Tekirdağ.

Okatan, A. (1987). Trabzon-Meryemana Deresi Yağış Havzası Alpin Meralarının Bazı Fiziksel ve Hidrolojik Toprak Özellikleri ile Vejetasyon Yapısı Üzerine Bir Araştırma. T.C. Tarım Orman ve Köy işleri Bakanlığı Orman Genel Müdürlüğü Yayınları. No: 664, Seri No: 62, s. 290.

Öner, T. (2006). Korunan Otlatılan ve Sürülüp Terk Edilen Mera Alanlarının Bitki Örtülerinin Karşılaştırılması. Atatürk Üniversitesi Fen Bilimleri Enstitüsü, Yüksek Lisans Tezi, s. 41. Erzurum.

Özen, F. \& Türk, M. (2014). Orman içi merada ağaç sıklığının bitki örtüsü üzerine etkileri. Turkish Journal of Forestry, 15(1), 9-14.

Özer, A. (1988). Osmaniye ilçesi, Kesmeburun Köyünde korunan bir mera ile otlatılan meraların bitki örtüsü ve verim güçlerinin saptanması üzerinde bir araştırma. 
Çukurova Üniversitesi Fen Bilimleri Enstitüsü. Yüksek Lisans Tezi, s. 41. Erzurum.

Özkan, U. \& Demirbağ, Ş.N. (2016). Türkiye'de kaliteli kaba yem kaynaklarının mevcut durumu. Türkiye Bilimsel Derlemeler Dergisi, 9(1), 23-27.

Sönmeyen, B.G. (2019). Kuruca Yaylası Merasının (AntalyaKaş) Vejetasyon Yapısı Üzerine Bir Araştırma. Isparta Uygulamalı Bilimler Üniversitesi Lisansüstü Eğitim Enstitüsü. Yüksek Lisans Tezi, s. 57. İsparta.

Şen, N. (2012). Kahramanmaraş İli Ahır Dağı Meralarının Bazı Hidrofiziksel ve Kimyasal Toprak Özellikleri ile Vejetasyon Yapısı Üzerine Araştırmalar. Kahramanmaraş Sütçü İmam Üniversitesi Fen Bilimleri Enstitüsü. Yüksek Lisans Tezi, s. 80. Kahramanmaraş.

Taşdemir, V. (2015). Elâzı̆̆ ili Karakoçan ilçesi Bahçecik köyü merasinda verim ve botanik kompozisyonunun saptanmas1 üzerine bir araştırma. Bingöl Üniversitesi Fen Bilimleri Enstitüsü. Yüksek lisans Tezi, s. 121. Bingöl.

Tekeli, S. \& Mengül, Z. (1991). Orman içi Merada Topografyanın Botanik Kompozisyona ve Verim Üzerine Etkisi. Türkiye II. Çayır-Mera ve Yem Bitkileri Kongresi. (s. 139-149). 28-31 Mayıs, İzmir.

Tiedeman, J. \& Motsamai, B. (1981). What is range management ? Circular RM-1. Maseru, Lesothos, Research Division, Ministry of Agriculture.

Tosun, F. (1996). Türkiye'de kaba yem üretiminde çayır-mera ve yem bitkileri yetiştiriciliğinin dünü, bugünü ve yarını. Türkiye III. Çayır-Mera ve Yem Bitkileri Kongresi. (s. 1-4). 17-19 Haziran, Erzurum.

TÜIK, (2018). Türkiye İstatistik Kurumu. www.tuik.gov.tr. Son erişim tarihi: 03.12.2019

Türker, A.H. (2006). Mersin Tarsus Oluk Koyak Köyü Topak Ardıç mevkiinde 1997 yılından beri korunmuş ağaçlandırma sahasındaki otsu vejetasyonun özellikleri üzerine bir araştırma. Doğu Akdeniz Orman Araştırma Müdürlüğü Doğa Dergisi, 12, 1-39.

Uluocak, N. (1978). Kırklareli Yöresi Orman İçi Mera Vejetasyonunun Nitelikleri ve Bazı Kantitatif Analizleri. İstanbul Üniversitesi Orman Fakültesi Yayınları No: 2407, İstanbul Üniversitesi Orman Fakültesi Yayınları No: 253, s. 116.

Uzun, F., Garipoğlu, A.V. \& Algan, D. (2009). Meralarımızda görülen sarı peygamber çiçeği (Centaurea solstitialis L.)'nin bitkisel özellikleri ve kontrolü. Samsun Anadolu Tarım Bilim Dergisi, 25(3), 213-222.

Yılmaz, M. \& Büyükburç, U. (1996). Tokat ili askeri gazinosunda korunan doğal bir mera vejetasyonunun ekolojik ve fitososyolojik yönden incelenmesi üzerine bir araştırma. Atatürk Üniversitesi Ziraat Fakültesi Tarla Bitkileri Bölümü, Türkiye 3. Çayır Mera ve Yem Bitkileri Kongresi. (s. 146-152). 17-19 Haziran, Erzurum. 